\title{
Problems in Assessment of Wind Energy Potential and Acoustic Noise Distribution when Designing Wind Power Plants
}

\author{
Valerijs Bezrukovs ${ }^{1}$, Vladislavs Bezrukovs ${ }^{2},{ }^{1-2}$ Ventspils University College, Nikolajs Levins, \\ Institute of Physical Energetics
}

\begin{abstract}
Interest in the use of renewable energy in Latvia is increasing every year. Government support and availability of large unpopulated areas on the coast makes the use of these lands for the placement of large wind power plants (WPP) attractive. The key factors that determine the choice of the location of WPP are reliable information about distribution of the resource of wind energy in this area and the influence of wind turbines on the environment. The paper presents the results of years-long observations on the density fluctuations of wind energy at heights of 10 to $60 \mathrm{~m}$ in the area in the Baltic Sea coast in Ventspils and Ainaži. The velocity observations since 2007 have been gathered by measurements complex of the LOGGER 9200 Symphonie type. The results are presented in the form of tables, bar charts and graphs. Extrapolation results of wind velocity and density mean values on heights up to $150 \mathrm{~m}$ for the two areas with different terrain types were shown. The distribution of acoustic noise in the vicinity of the WPP was studied and an assessment of its impact on the environment in accordance with the Latvian government requirements was conducted.
\end{abstract}

Keywords - acoustic noise level, measurement of wind speed, radioastronomy, wind energy, wind speed approximation at $150 \mathrm{~m}$

\section{INTRODUCTION}

The availability of large unpopulated coastal areas and the developed infrastructure of electric power networks in the Baltic countries make the use of these areas for locating large wind power plants (WPP) attractive. In the coastal territories of western Estonia, in the Ida-Virumaa region at the site of the former shale quarries, the construction of WPPs is planned, the power of which will be over $600 \mathrm{MW}$. Further it is also planned to start offshore WPP construction. In Latvia, projects on the construction of $450 \mathrm{MW}$ coastal WPPs have been approved; there are also projects planned for the construction of a $900 \mathrm{MW}$ wind park offshore. In Lithuania, the total power of wind parks in 2010 has made up $200 \mathrm{MW}$, with $1000 \mathrm{MW}$ to be reached; after 2020 it is planned to start works in the offshore territories. In Latvia, planned preparation of the infrastructure is taking place: construction of thermal power plants and of the transmission line "Kurzeme Arc" (by 2017), which would allow for the construction of a $~ 900 \mathrm{MWWPP}$ in the sea near the city of Liepaja (by 2020). Governmental support is confirmed by working out administrative and legislative regulations, as well as by creating a favourable tariff policy that would encourage the construction of large WPPs. At the same time, for the territory of the Baltic countries, there are no databases of long-term measurements of wind speeds at different heights that can be used to compose an atlas of wind energy resource distribution in this region. The systematic long-term measurements of wind speeds in Latvia since 2007, taking into account the wind speed distribution on several levels, have been carried out in two sites: on the south-west coast of the Baltic Sea in the Ventspils region and on the north of the country in the Ainaži region, $35 \mathrm{~km}$ from the shore [1].

The first metrological mast is located in Irbene (Ventspils region) in the territory of the Ventspils International Radioastronomy Centre (VIRAC). Information about wind speeds collected from this mast was also used to study wind influence on radio telescopes. VIRAC operates two parabolic fully steerable radiotelescopes: RT-32: $32 \mathrm{~m}$ antenna with the surface area of 800 sq.m and RT-16: $16 \mathrm{~m}$ antenna with the area of 220 sq.m. Reliable information about current wind conditions is very important for radio astronomical observations, because wind speeds higher than $11 \mathrm{~m} / \mathrm{s}$ may influence the shape of the antenna and, therefore, may disturb radio astronomical observations. Furthermore, wind speeds higher than $15 \mathrm{~m} / \mathrm{s}$ make radio astronomical observations impossible.

The second metrological mast is located in a town called Matiši, near Lake Burtnieku (Ainaži region). This mast is mainly used to collect information about the wind potential in this area, especially for subsequent construction of a wind power plant. The metrological mast installation process is shown in Figure 1. The installed NRG mast is shown in Fig. 2.

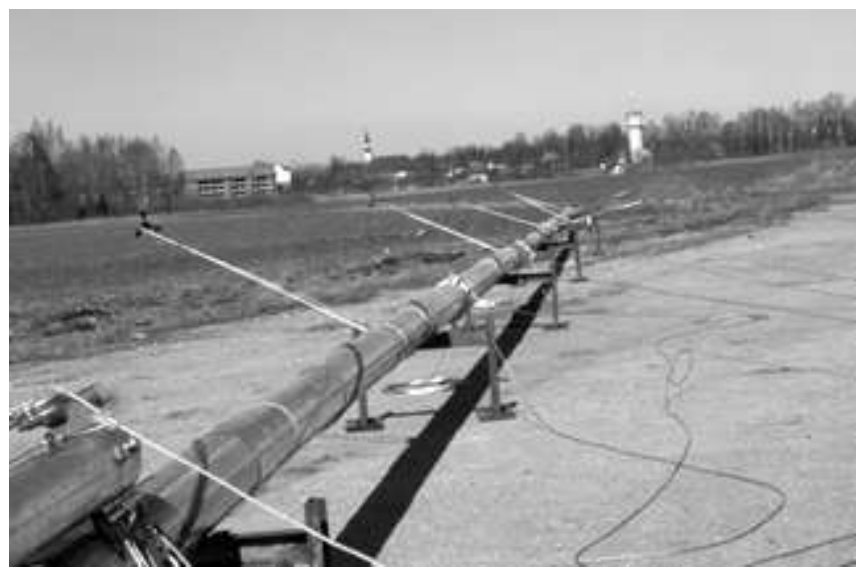

Fig 1. Installation of the NRG metrological mast with wind speed sensors in Matiši, Ainaži region. 


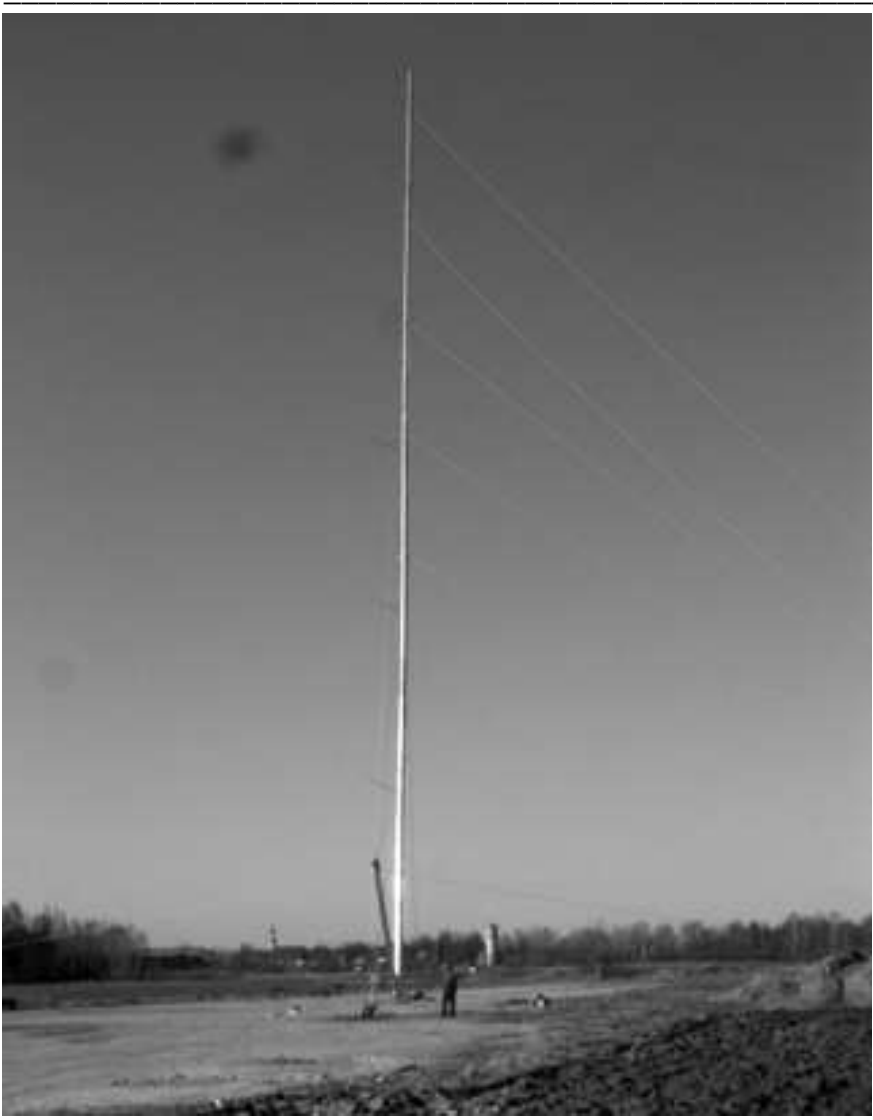

Fig. 2. NRG metrological mast, $60 \mathrm{~m}$ heigh, installed in Matiši, Ainaži region.

\section{RESEARCH ON THE CYCLIC BEHAVIOUR OF WIND ENERGY FLUCTUATIONS}

The measurements of wind speed were carried out using certified and calibrated sensors of wind speed of the NRG \#40 type and sensors indicating the direction of the air stream of the NRG \#200P type. The sensors are arranged on metallic masts up to heights of 53 and $60 \mathrm{~m}$ above the ground (Table 1).

The periodicity of the information read-out from the sensors at all the height levels was $10 \mathrm{~s}$. An NRG LOGGER Symphonie complex (Figure 3), which has an independent supply from batteries and is able to store information from nine sensors in the memory card during a year, was used for storing information.

The retrieval and filtering of wind data from both sites was done by using the NRG Symphonie Data Retriever shown in Figure 4. The further data analysis was conducted by using Microsoft Excel 2007 with additional scripts. During the observation period, a database was created containing wind speed values at the heights of $10,20,30,40,50$ and $60 \mathrm{~m}$, as well as wind temperature and direction in two regions in the Latvian territory. Figures 5 and 6 show wind roses typical for these regions. For the Ventspils (Irbene) site, the data from the height of $53 \mathrm{~m}$ were used and, for the Ainaži (Matiši) site, the data from the height of $60 \mathrm{~m}$ were used.

At present, the database contains more than 3'500'000 records of measurements. In order to compare the wind energy flow levels on the sea shore in Irbene to those of the area remote from the sea in the Ainaži region, the average wind speed values, $V_{a}$, are given in Table 2 with standard deviations $(S D)$, and the wind energy density values, $P_{d}, W / m^{2}$. The dark colour in the table corresponds to a larger value of wind speed or energy density for the month.

The charts of seasonal fluctuations of the average wind speed $V(\mathrm{~m} / \mathrm{s})$ for the measurement period $T$ (a month) at the heights 20,30,40,50 $\mathrm{m}$ in the Ventspils region and 10,30, 50, $60 \mathrm{~m}$ in the Ainaži region are shown in Figures 7 and 8. The results of the wind speed measurements taken in the Ventspils and Ainaži regions are systematised and presented in the form of histograms in Figures 9 and 10. The envelope of the histogram shows the wind speed $V$ distribution in the relative frequency of repetition $F$, which corresponds to the relation, where $T_{V}$ is the total duration of wind with the speed $V$ in the whole measurement period $T$ for the heights $20,30,40,50 \mathrm{~m}$ in the Ventspils region and 10,30, 50, $60 \mathrm{~m}$ in the Ainaži region.

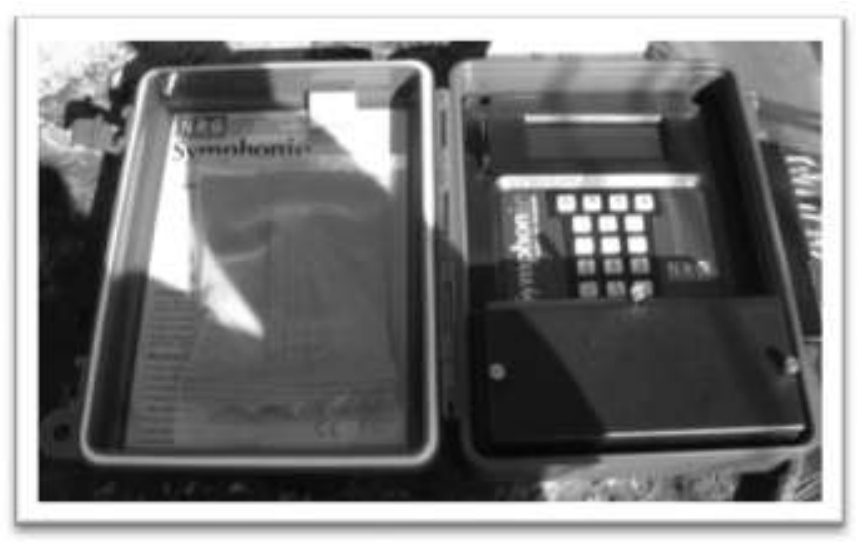

Fig. 3. NRG LOGGER Symphonie complex used for storing data.

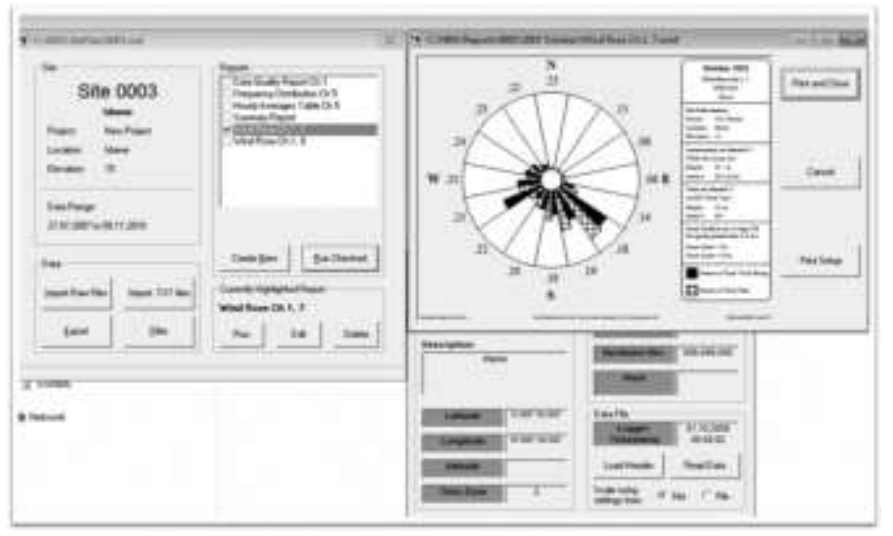

Fig. 4. NRG Symphonie Data Retriever used for data retrieving and filtering.

The histogram makes it possible to determine the wind energy flow density, which is calculated by the equation:

$$
P_{d}=\rho \frac{V_{a \cdot c \cdot}^{3}}{2}=\rho \frac{\sum_{n=0}^{n} V_{n}^{3} F_{n}}{2 \times 100},
$$

where $V_{a . c}-$ is the average cubic wind speed, $\mathrm{m} / \mathrm{s}$,

$\rho=1.23 \mathrm{~kg} / \mathrm{m}^{3}-$ is the air density at atmosphere pressure $101.325 \mathrm{kPa}$ and temperature $15^{\circ} \mathrm{C}$, 
$V_{n}-$ is the wind speed, $\mathrm{m} / \mathrm{s}$,

$F_{n}-$ is the relative frequency of repetition, $\%$, corresponding to wind speed $V_{n}$ and determined by curves on the histogram of Figure 4.

From analysis of the statistical data for 2009/2011 shown in Figure 11, it follows that in the coastal zone winds are gustier,

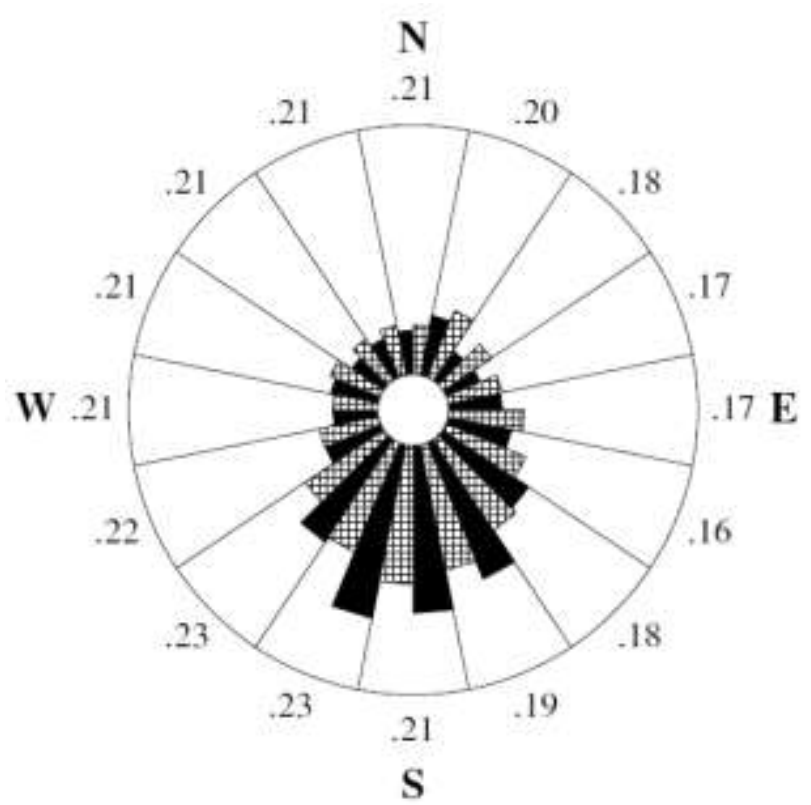

Fig. 5. Wind rose for the measurement period August 2007 - November 2010. Irbene, Ventspils region. Outer numbers are average TIs for wind speed greater than $4.5 \mathrm{~m} / \mathrm{s}$. Fields filled with black colour indicate total wind energy, checkered fields show wind total time. whereas farther from shore their speeds are more uniform. The maximum value for separate wind gusts lasting not less than $10 s$ in the Ventspils region is not much higher than in Ainaži, with the situation changing in individual months. In January of 2005 the wind gusts in the Ventspils region at a height of $50 \mathrm{~m}$ reached $34.1 \mathrm{~m} / \mathrm{s}$.

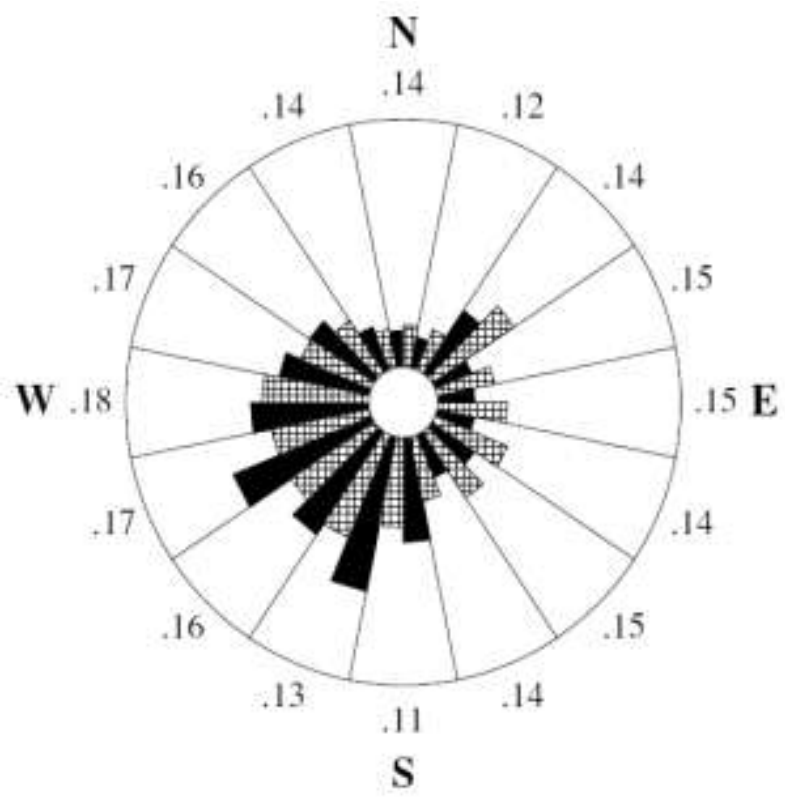

Fig 6. Wind rose for the measurement period April. 2009 - November 2010, Matiši, Ainaži region. Outer numbers are average TIs for wind speed greater than $4.5 \mathrm{~m} / \mathrm{s}$. Fields filled with black colour indicate total wind energy, checkered fields show wind total time.

TABLE I

CHARACTERISTICS OF METEOROLOGICAL MASTS INSTALLED IN IRBENE AND MATIŠI

\begin{tabular}{|c|c|c|c|}
\hline & & Ventspils (Irbene) & Ainaži (Matiši) \\
\hline \multicolumn{2}{|c|}{ Instrument: } & NRG Metrological mast, height $53 \mathrm{~m}$ & NRG Metrological mast, height $60 \mathrm{~m}$ \\
\hline \multicolumn{2}{|c|}{ Site elevation: } & $15 \mathrm{~m}$ & $60 \mathrm{~m}$ \\
\hline \multicolumn{2}{|c|}{ Terrain type: } & $\begin{array}{l}\text { Baltic Sea coast, flat terrain covered with forest }(8-10 \\
\text { meters high trees) Mast distance from see: } \sim 5 \mathrm{~km} \text {. }\end{array}$ & $\begin{array}{l}\text { An open plain terrain remote from the sea. } \\
\text { Mast distance from see: } \sim 35 \mathrm{~km} \text {. }\end{array}$ \\
\hline \multicolumn{2}{|c|}{ Date of mast installation: } & 27.07.2007. & 11.04.2009. \\
\hline \multirow{4}{*}{ Sensors: } & Anemometer: & NRG \#40 Anemometer; Height (m): 20; 30; 40; 50; 53 & NRG \#40 Anemometer; Height (m): 10; 20; 30; 40; 50; 60 \\
\hline & Wind direction: & NRG \#200P Wind Vane; Height (m):20; 53 & NRG \#200P Wind Vane; Height (m): 50; 60 \\
\hline & Temperature: & NRG \#110S Temp; Height (m): 20 & NRG \#110S Temp; Height (m): 6 \\
\hline & Barometer: & NRG \#BR20 Barometer; Height (m): 10 & Not installed \\
\hline
\end{tabular}

TABLE II

DISTRIBUTION OF AVERAGE WIND SPEED VALUES WITH STANDARD DEVIATIONS AND CORRESPONDING POWER DENSITY VALUES AT THE HEIGHT 50 (M) IN THE OBSERVATION PERIOD

\begin{tabular}{|c|c|c|c|c|c|c|c|}
\hline & & \multicolumn{3}{|c|}{ Ventspils (Irbene) } & \multicolumn{3}{|c|}{ Ainaži (Matiši) } \\
\hline & & $V_{a}, \mathrm{~m} / \mathrm{s}$ & $S D \mathrm{~m} / \mathrm{s}$ & $P_{d}, W / m^{2}$ & $V_{a}, \mathrm{~m} / \mathrm{s}$ & $S D \mathrm{~m} / \mathrm{s}$ & $P_{d}, W / m^{2}$ \\
\hline \multirow{5}{*}{ 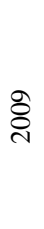 } & April & 4.27 & 0.78 & 76.92 & 4.48 & 0.72 & 85.53 \\
\hline & May & 4.82 & 0.97 & 93.59 & 4.58 & 0.81 & 93.10 \\
\hline & June & 4.80 & 0.99 & 95.32 & 4.56 & 0.84 & 97.48 \\
\hline & July & 4.28 & 0.83 & 77.96 & 3.87 & 0.65 & 57.99 \\
\hline & August & 4.37 & 0.80 & 73.82 & 4.14 & 0.67 & 64.92 \\
\hline
\end{tabular}




\begin{tabular}{|c|c|c|c|c|c|c|c|}
\hline & September & 5.04 & 1.03 & 113.19 & 4.61 & 0.74 & 83.86 \\
\hline & October & 4.78 & 1.07 & 151.59 & 5.00 & 0.79 & 139.02 \\
\hline & November & 4.97 & 1.12 & 103.52 & 4.73 & 0.79 & 84.99 \\
\hline & December & 4.23 & 0.88 & 81.45 & 3.98 & 0.63 & 66.16 \\
\hline \multirow{11}{*}{$\stackrel{\circ}{\stackrel{\overbrace{}}{\circ}}$} & January & 3.60 & 0.67 & 56.48 & 3.01 & 0.43 & 47.71 \\
\hline & February & 3.58 & 0.74 & 47.95 & 3.32 & 0.48 & 43.83 \\
\hline & March & 4.88 & 1.08 & 105.12 & 4.91 & 0.81 & 107.57 \\
\hline & April & 3.71 & 0.80 & 52.75 & 4.14 & 0.71 & 68.58 \\
\hline & May & 4.02 & 0.88 & 68.15 & 4.16 & 0.77 & 75.45 \\
\hline & June & 4.36 & 0.91 & 88.80 & 4.23 & 0.79 & 78.83 \\
\hline & July & 4.02 & 0.76 & 55.71 & 3.42 & 0.61 & 38.88 \\
\hline & August & 4.09 & 0.81 & 67.83 & 3.88 & 0.68 & 63.92 \\
\hline & October & 4.98 & 0.99 & 120.17 & 5.16 & 0.80 & 124.68 \\
\hline & November & 4.40 & 1.02 & 97.18 & 4.80 & 0.74 & 98.13 \\
\hline & December & 4.72 & 1.01 & 111.93 & 4.92 & 0.44 & 101.47 \\
\hline \multirow{8}{*}{$\underset{\sim}{\bar{D}}$} & January & 4.74 & 1.04 & 105.60 & 5.12 & 0.90 & 135.59 \\
\hline & February & 5.08 & 1.03 & 125.39 & 4.44 & 0.61 & 103.28 \\
\hline & March & 5.78 & 1.26 & 161.43 & 5.53 & 0.94 & 154.61 \\
\hline & April & 4.29 & 0.87 & 91.09 & & & \\
\hline & May & 4.59 & 0.92 & 91.93 & & & \\
\hline & June & 4.49 & 0.90 & 79.82 & & & \\
\hline & July & 3.90 & 0.79 & 51.10 & & & \\
\hline & Average & 4.49 & 0.93 & 91.50 & 4.41 & 0.71 & 88.47 \\
\hline
\end{tabular}

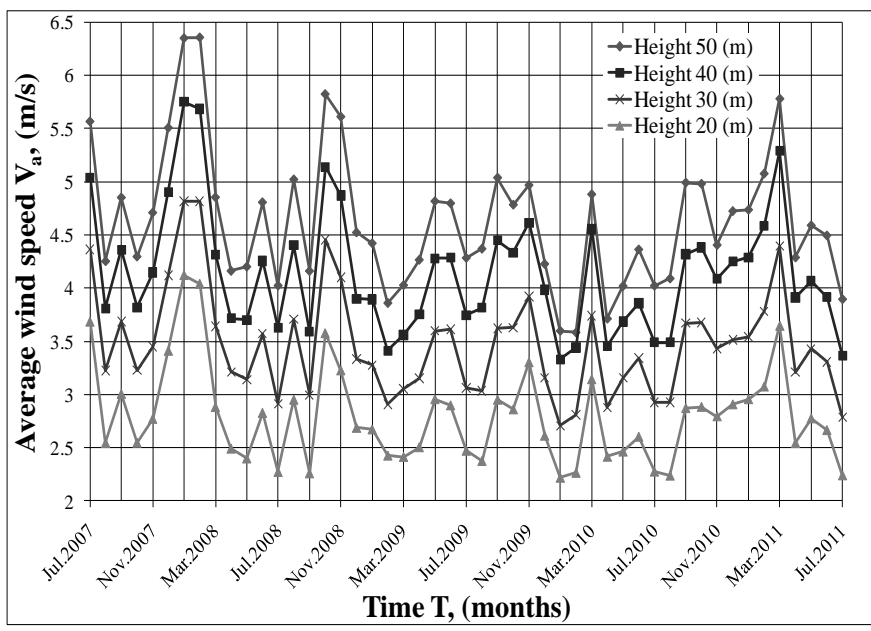

Fig. 7. Average wind speed values $V_{a}$ in period $\mathrm{T}(2007 / 2011)$ at heights 10 , 30,40 and $50(\mathrm{~m})$ in the Ventspils region.

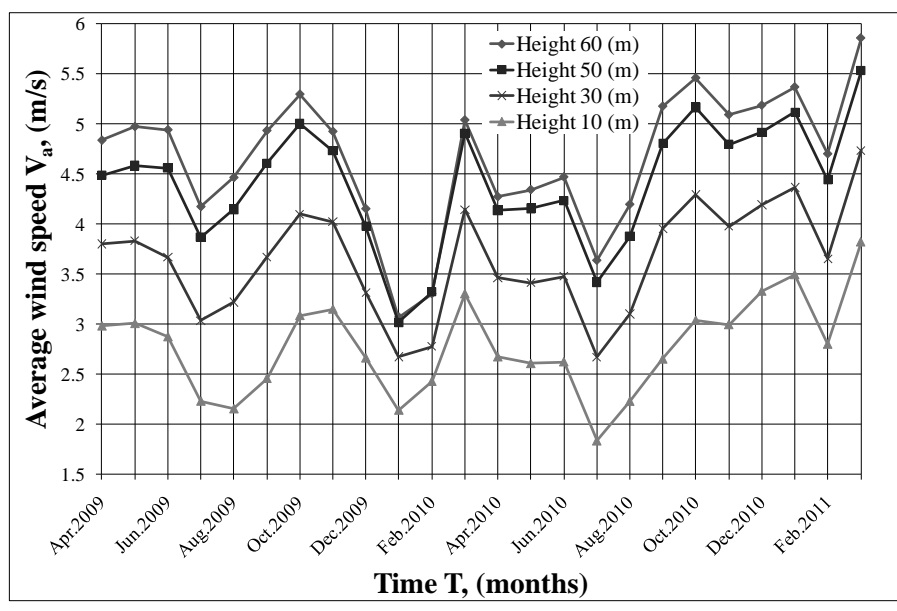

Fig. 8. Average wind speed values $V_{a}$ in period $\mathrm{T}(2009 / 2011)$ at heights 10 , 30,50 and $60(\mathrm{~m})$ in the Ainaži region. 


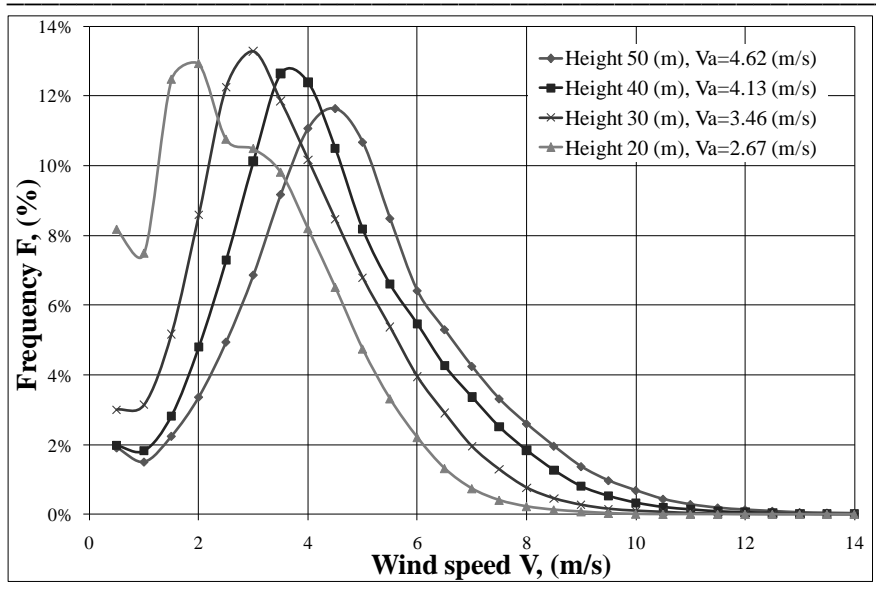

Fig. 9. Distribution of wind speed in relative frequency of repetition $F=f(V)$ at heights $10,30,40$ and $50(\mathrm{~m})$ in the Ventspils region

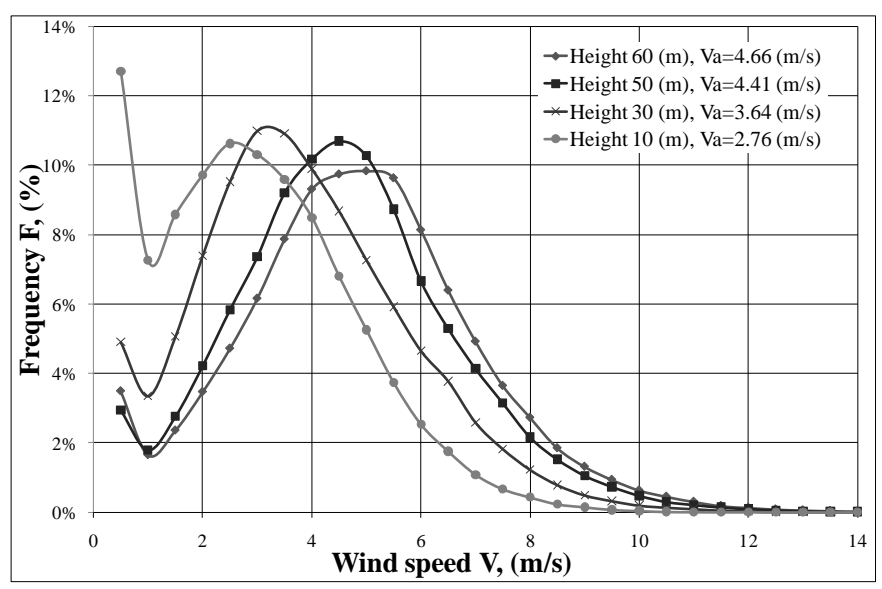

Fig. 10. Distribution of wind speed in relative frequency of repetition $F=f(V)$ at heights 20,30,50 and $60(\mathrm{~m})$ in the Ainaži region.

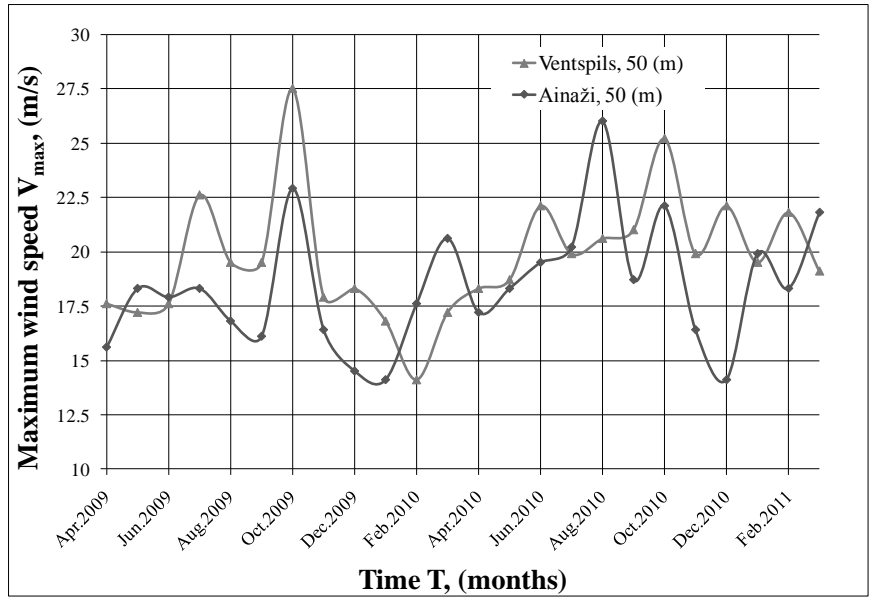

Fig.11. The maximum values of separate wind gusts, $V(\mathrm{~m} / \mathrm{s})$, with duration 10 $(\mathrm{s})$ in the regions Ventspils and Ainaži, at height $50(\mathrm{~m})$ above ground level in the period of $2009 / 2011$.

\section{APPROXIMATING FUNCTIONS FOR THE CALCULATION OF WIND SPEED AND WIND ENERGY DENSITY}

The distribution curves of the average wind speed $V_{a}(\mathrm{~m} / \mathrm{s})$ in height $h(m)$ above the ground level in the Ventspils and Ainaži regions which were obtained based on the data accumulated for a time are presented in Figure 12. The measured values of wind speed in the Ventspils region are shown by two curves. Curve 1 corresponds to the average wind speed values in the period of 2007/2011, Curve 2 - to the average wind speed values in the period of 2009/2011, and Curve 3 - to the distribution of the average wind speed in the Ainaži region in the period of 2009/2011.

Analysis of the distribution curves in Figure 12 obtained for the average wind speed $V_{a}$ shows that the wind speed distribution in the height up to $30 \mathrm{~m}$ is to a considerable extent determined by the topography of the terrain. In the Ventspils region, this terrain is represented by $8-10 \mathrm{~m}$ high tract of forest, whereas in the Ainaži region - the area is an open field $30 \mathrm{~km}$ further from the sea. The points on the curves corresponding to the measured values of wind speed at a height over $30 \mathrm{~m}$ could be well approximated by the exponential function of the form:

$$
V_{\alpha}=k h^{\alpha}
$$

For the curves of Fig. 13, the following values for approximating functions have been obtained:

For Curve $1-V_{a}=1.19 h^{0.37}$, the coefficient of determination $R^{2}=0.993$;

For Curve $2-V_{a}=1.17 h^{0.37}$, the coefficient of determination $R^{2}=0.992$;

For Curve $3-V_{a}=1.09 h^{0.36}$, the coefficient of determination $R^{2}=0.998$,

hereafter $R^{2}$ - reveals how close the modelled approximation function is to the actual measured values, being the most reliable when it is at or near 1 .

Figure 13 shows Curves 1, 2, 3 for measured values of the average wind speed $V_{a}(\mathrm{~m} / \mathrm{s})$, which are calculated using the corresponding values of approximating functions and are extrapolated up to the height $h$ of $150 \mathrm{~m}$. The following coefficients and exponents have been obtained for approximating function in Eq. (2) from the analysis of the distribution of the average cubic wind speed depending on the height above the surface $V_{\text {a.c. }}=f(h)$ for curves $1,2,3$ :

For Curve $1-V_{a . c}=1.69 h^{0.31}$, the coefficient of determination $R^{2}=0.987$;

For Curve $2-V_{\text {a.c. }}=1.66 h^{0.31}$, the coefficient of determination $R^{2}=0.987$;

For Curve $3-V_{a . c}=1.67 h^{0.29}$, the coefficient of determination $R^{2}=0.999$.

With due regard for the relationship in Eq. (1) the distribution curves for the average cubic wind speed values in height $V_{\text {a.c. }}=f(h)$ are calculated up to the height of $150 \mathrm{~m}$ and are presented in Figure 14. Correspondingly, the distribution curves for the wind energy density $P_{d}=f(h)$ are presented in Figure 15. The next functions have been used to calculate wind energy density in the coastal area and in the regions located from the coast by $30-40 \mathrm{~km}$ :

For Curve $1-P_{d}=3.14 h^{0.93}$ the coefficient of determination $R^{2}=0.987$;

For Curve $2-P_{d}=2.90 h^{0.93}$, the coefficient of determination $R^{2}=0.987$; 
For Curve $3-P_{d}=3.01 h^{0.86}$, the coefficient of determination $R^{2}=0.999$.

For flat territories typical of the Baltic countries, the approximating function Eq. (2) could be reduced to a form more convenient for use, as shown in the Eq. (3) \& Eq. (4):

$$
\begin{gathered}
V_{\alpha \cdot \boldsymbol{h}}=V_{\alpha \cdot \boldsymbol{h}_{1}}\left(\frac{\boldsymbol{h}}{\boldsymbol{h}_{\mathbf{1}}}\right)^{\alpha}, \\
V_{\alpha \cdot \boldsymbol{h}}=V_{\alpha \cdot \boldsymbol{h}_{1}}\left(\frac{\boldsymbol{h}-\boldsymbol{h}_{\mathbf{0}}}{\boldsymbol{h}_{\mathbf{1}}-\boldsymbol{h}_{\mathbf{0}}}\right)^{\alpha},
\end{gathered}
$$

where $V_{a . h}-$ is the calculated value of the average wind speed $(\mathrm{m} / \mathrm{s})$ at height $h,(\mathrm{~m})$;

$V_{a \cdot h_{1}}$ is the measured value of the average wind speed $(\mathrm{m} / \mathrm{s})$ at height $h_{l},(\mathrm{~m})$ for a flat area;

$h_{0}-$ is the height of the surface relief at the installation point of the measuring set,

$\alpha-$ is the approximation coefficient (depending on remoteness from the sea shore is $0.37-0.31$ ).

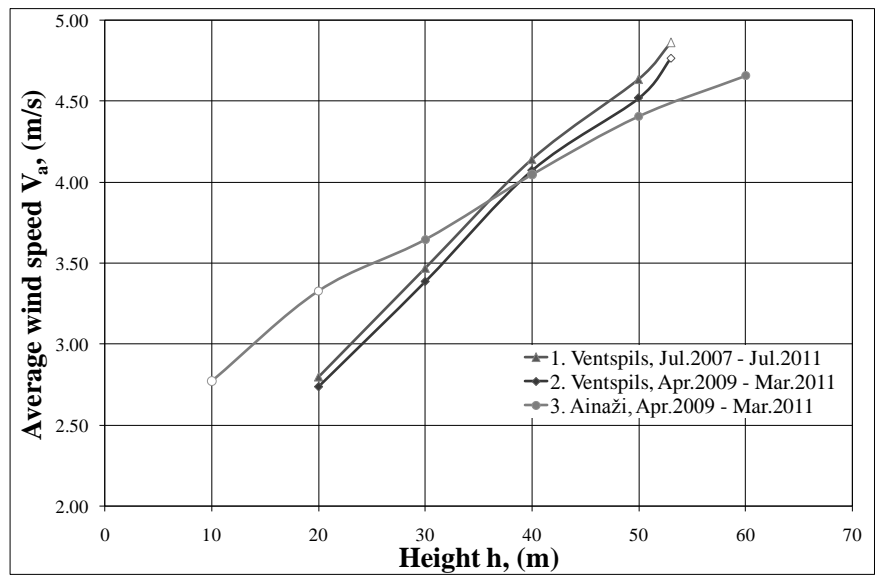

Fig. 12. The curves of the average wind speed vs. height $V_{a}=f(h)$ in the Ventspils and Ainaži regions obtained by measurements.

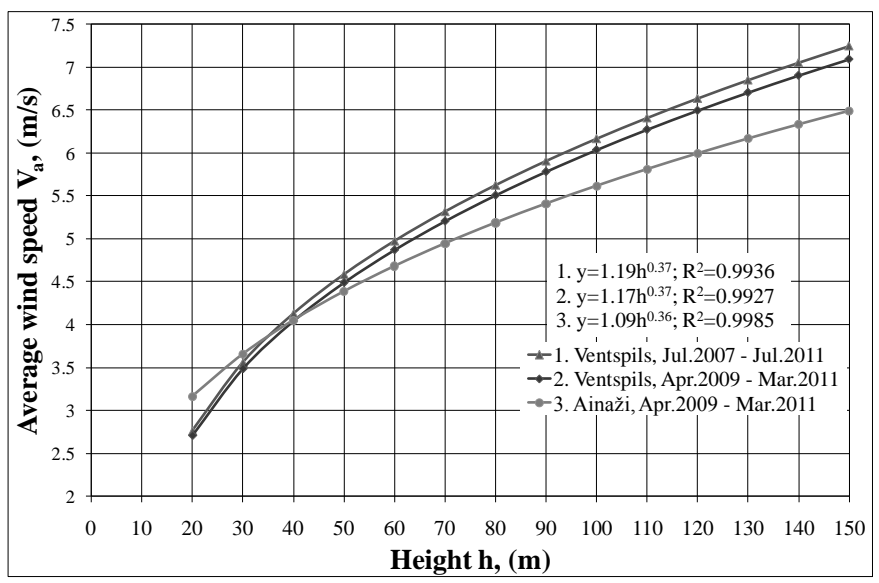

Fig. 13. The curves of the average wind speed $v s$. height $V_{a}=f(h)$ in the Ventspils and Ainaži regions extrapolated up to the height of $150(\mathrm{~m})$.

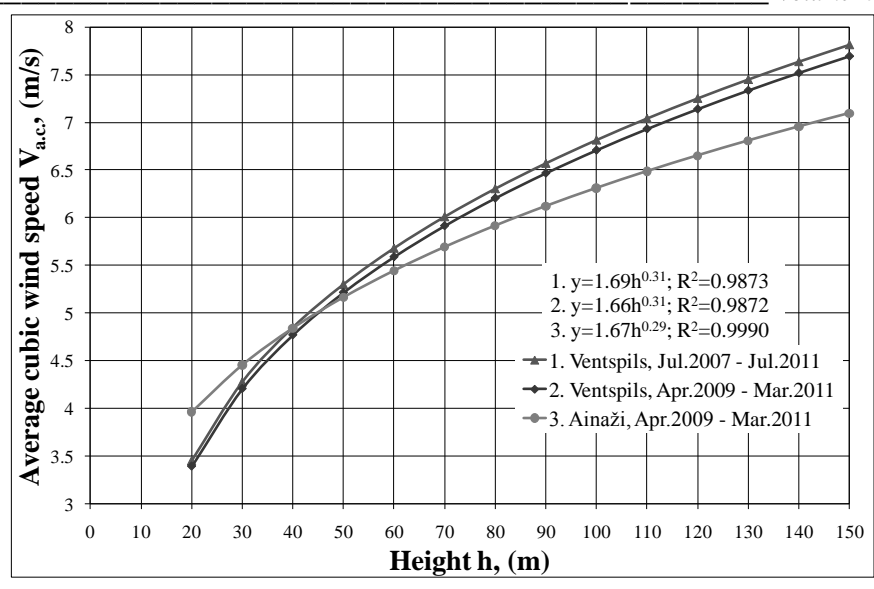

Fig. 14. The curves of the average cubic wind speed vs. height $V_{\text {a.c. }}=f(h)$ in the Ventspils and Ainaži regions extrapolated up to the height of $150(\mathrm{~m})$.

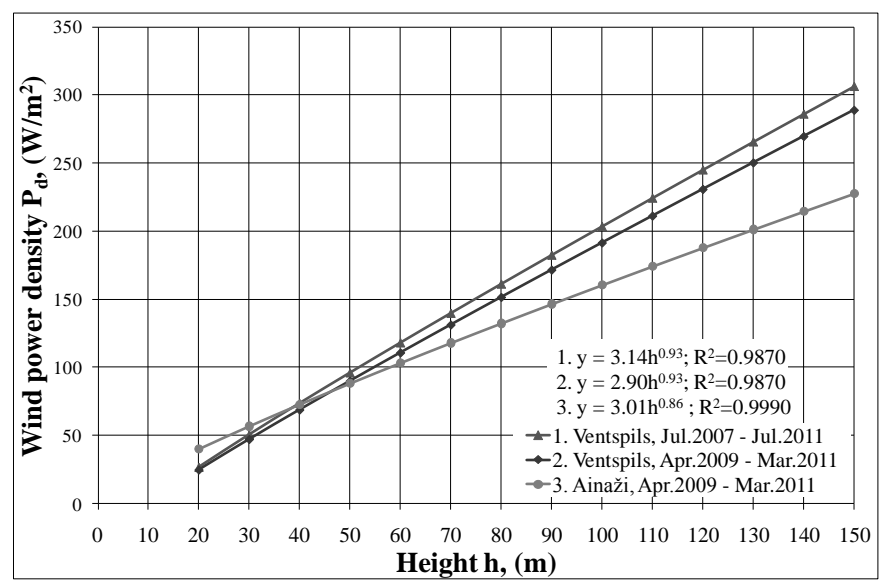

Fig. 15. The curves of the wind energy density vs. height $P_{d}=f(h)$ in the Ventspils and Ainaži regions extrapolated up to the height of $150(\mathrm{~m})$.

\section{ESTIMATION OF THE ACOUSTIC NOISE LEVEL DISTRIBUTION AROUND A WPP}

Selection of a location for construction of wind power plants depends not only on the wind speed in this area, but also on the maximum permissible impact on the environment, where it is planned to setup wind turbines.

One of the negative aspects of WPP operation is the emission of low-frequency noise that affects humans and disturbs comfortable living conditions. Calculations make it possible to define a zone of noise influence on the environment and to determine if the planned projects are in accordance with the requirements of Latvian legislation [3], which establishes standards for noise levels in populated areas. In compliance with the sanitary norms in Latvia, the noise level acceptable in places where people permanently reside must not exceed $40 \mathrm{~dB}(A)$. This means that construction of WPPs in close proximity to settlements is not allowed.

Figure 16 shows the map of the noise level distribution in the territory surrounding a WPP, consisting of 32 generators with the total power of $80.0 \mathrm{MW}$ in the Ainaži region. The maximum value of the noise level in the WPP territory is $50.14 d B(A)$, the noise level of a generator being $99.0 d B(A)$ [4]. 


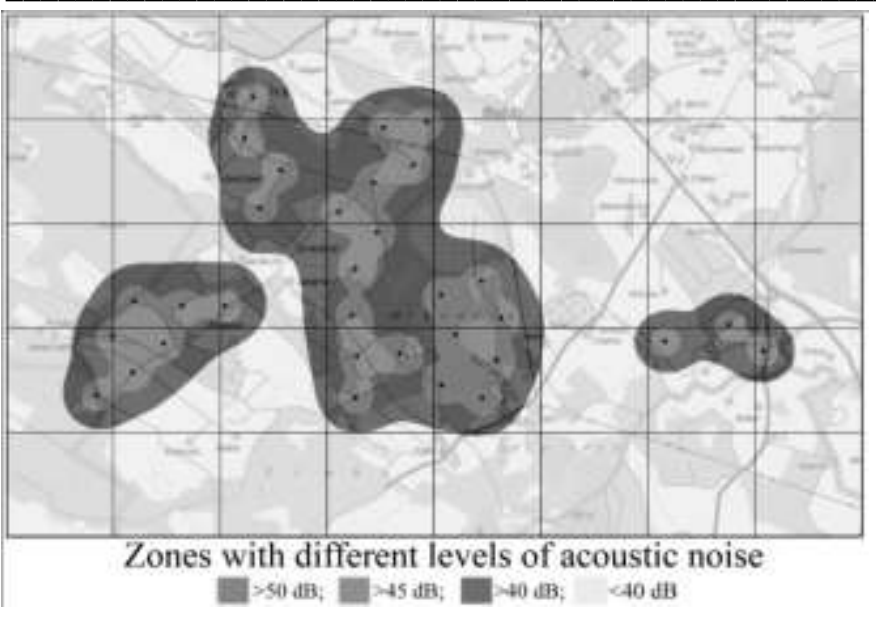

Fig. 16. The map of noise level distribution around a WPP consisting of 32 generators with the total power of 80.0 (MW) in the territory 8000x5000 (m).

\section{V.CONCLUSIONS}

1. The availability of large unpopulated areas on the coasts of the Baltic countries, along with the developed infrastructure of electric power networks, makes the use of these lands for situating large wind power plants (WPPs) attractive.

2. During long-term observations a statistical database has been established with data on the distribution of speeds and directions of winds at different heights: 10, 20, 30, 40, 50 and $60 \mathrm{~m}$ in the Ventspils and Ainaži regions on the Baltic Sea shore.

3. The graphs of seasonal fluctuations of wind speeds have been obtained for the heights up to $60 \mathrm{~m}$ by measurements over the period of $2007-2011$.

4. Histograms have been developed for the relative frequency of the repetition of wind speeds over the period of 2007 2011.

5. The values of approximating functions have been obtained, making it possible to calculate wind speeds at a height of up to $150 \mathrm{~m}$ above ground level in the coastal zones of the Baltic Sea and in a territory at a distance of $35 \mathrm{~km}$ from the sea.

6. The wind speed measurements are noticeably affected by the features of the terrain, and, therefore, in order to raise the precision for the determination of approximating functions, it is worthwhile to use measuring sensors only at a height over $30 \mathrm{~m}$ above the ground level.

7. The maximum values obtained for separate wind gusts lasting no less than $10 \mathrm{~s}$ are not much higher in the Ventspils region than in the Ainaži region. In January 2005 wind gusts at a height of $50 \mathrm{~m}$ reached $34.1 \mathrm{~m} / \mathrm{s}$ in the Ventspils region.

8. The level of acoustic noise within the area where WPPs are located can reach levels higher than $50 \mathrm{~dB}(A)$, although, in compliance with the sanitary norms, the noise levels permissible for residential areas must not exceed $40 \mathrm{~dB}(A)$.

\section{ACKNOWLEDGMENTS}

The authors acknowledge support from Encom Ltd, Ventspils University College and ESF Human resources project Nr. 2009/0231/1DP/1.1.1.2.0/09/APIA/VIAA/151 "Receiving, Transmitting and Processing Technologies of Signals Related to Artificial Earth Satellites".

\section{RERERENCES}

1. P. Shipkovs, V. Bezrukov, V. Pugachev, Vl. Bezrukovs, V. Silutins, Research of the wind energy resource distribution in the Baltic region, In proceedings of the Conference World Renewable Energy Congress XI, 2010, Abu Dhabi, UEA, pp.1931 - 1936.

2. P. Shipkovs, V. Bezrukov, Vl. Pugachov, Vl. Bezrukovs, S. Orlova „Measurements and utilization of wind energy on the Baltic Sea coast". In proceedings of the Conference The 10th World Renewable Energy Congress, 2008, Glasgow, Scotland, pp. 2398 - 2403.

3. LVS ISO 9613-2:2004 "Akustika - Skaņas vājinājums, tai izplatoties arējā vidē - 2.daḷa: Vispārīga aprēkina metode" prasības un Ministru kabineta noteikumi Nr.597 (Vides trokšņa novērtēšanas kārtība). Revision 02.09.2008.

4. P. Shipkovs, V. Bezrukov, V. Pugachev, Vl. Bezrukovs, V. Silutins. "Measurements of the wind energy resource in Latvia" In proceedings of the Conference World Renewable Energy Congress, WREC $2011-$ Sweden 8-13 May 2011, Linköping, 0724 WE. 8 pp.

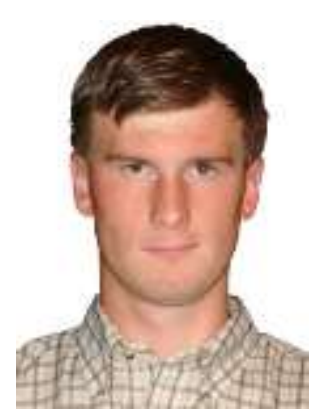

Vladislavs Berzrukovs, Mg.sc.ing., researcher in the Engineering Research Institute "Ventspils International Radio Astronomy Centre" of Ventspils University College. Vladislavs Bezrukovs has been part of academic staff of VIRAC since 2008. The main research areas are radio astronomy and wind studies. He has the computer science and computer engineering diploma (2005) and currently works on $\mathrm{PhD}$ thesis "Multiwavelength Analysis of BL Lacertae Objects". He has participated in different international projects related to radio astronomy (ENIGMA) and wind energy studies (NORSEWInD). From 2005 to 2008 studied in Cork Institute of Technology, Applied Physics Department, Cork, Ireland. Since 2008 he is member of Committee on Radio Astronomy Frequencies, an Expert Committee of the European Science Foundation. He is the author of 11 scientific publications and patents. Research interests: radio astronomy, Active Galactic Nuclei, wind measurements and modeling, acoustic noise of wind power parks, mathematical modeling, programming.

Address: Inženieru 101, LV-3605, Ventspils, Latvia

Phone: +371 27134283

E-mail: vladislavsb@venta.lv

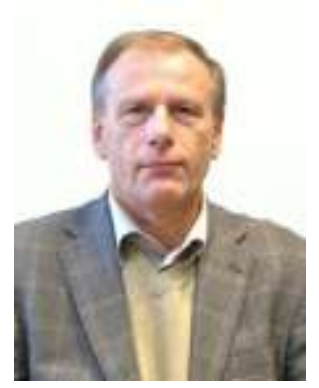

Valerijs Bezrukovs, Dr.hab.sc.ing. Senior researcher in the Institute of Physical Energetics, Riga and in the Engineering Research Institute "Ventspils International Radio Astronomy Centre" of Ventspils University College, Ventspils, Latvia. Dr. Valerijs Bezrukovs has been part of academic staff of Ventspils International Radio Astronomy Centre since 1994. From 1968 to 1974 he studied at Riga Technical University, Faculty of Power and Electrical Engineering and specialised in electro mechanics. After diploma, he started to work at the Latvian Academy of Sciences, the Institute of Physical Energetics, where Valerijs Bezrukovs worked on adjusting the synchronous motor control systems for use in oil extraction plants. He defended PhD thesis in 1983. In 1987 Valerijs finished Government Advanced Training courses on patenting and was elected as head of Institute of Physical Energetics Patenting Department. In 1992 he got the doctoral degree diploma in VNIIelectromash, St. Petersburg, Russia. In 1993 he got the Dr.sc.ing. degree and was elected as Senior Researcher in Institute of Physics Energetics, where he worked in electromotor and wind energy fields. Since 1994, he worked on reconstruction of Irbene radio telescope RT-32 and RT-16. From 2005 he is the chief 
engineer and senior researcher at the Ventspils International Radio Astronomy Centre. Research interests: control of electrical machines, wind energy measurement, acoustic noise of wind parks. More than 70 scientific publications, including 40 patents.

Address: Aizkraukles 21, LV-1006, Riga, Latvia

Phone: +371 29147160

E-mail: valerijs.bezrukovs@venta.lv
Nikolajs Levins, Dr.habil.sc.ing., Senior researcher in the Institute of Physical Energetics. Research interests: construction of electrical machines, wind energy measurement, acoustic noise of wind parks.

E-mail: elmag@inbox.lv

Valerijs Bezrukovs, Vladislavs Bezrukovs, Nikolajs Levins. Potenciālās vēja enerğijas un akustiskā trokšṇa sadalǐšanās novērtēšanas problēmas, projektējot vēja elektrostacijas.

Baltijas valstīs aug interese par atjaunojamās enerǵijas avotu izmantošanu. Valsts atbalsts un lielas, neapdzīvotas platības jūras piekrastē padara šīs zemes platības pievilc̄̄gas lielu vēja elektrostacijas parku izvietošanai. Plānojamo projektu sekmīgai realizācijai ir nepieciešama droša un ticama informācija par vēja enerǵijas resursu izvietojumu augstumā līdz $150 \mathrm{~m}$ virs grunts līmeņa. Pētījumus šajā jomā veic Fizikālās enerḡêtikas institūts, sadarbojoties ar Ventspils augstskolu. Rakstā analizēti mērījumu rezultāti par daudzgadīgiem vēja ātruma mērījumiem augstumā no 10 līdz 60 metriem. Balstoties uz šiem rezultātiem, tika sastādīts vēja enerǵijas izvietojums augstumā virs Baltijas jūras piekrastes Latvijas ziemeḷu un dienvidrietumu dạ̦ā. Vēja ātruma mērījumi tika veikti izmantojot mērišsanas kompleksu LOGGER 9200 Symphonie un sertificêtus vēja ātruma un virziena sensorus. Tika veikta vēja ātruma analīze pēc augstuma, balstoties uz iegūto datu bāzi, kas sastāv no vairāk nekā 3'500'000 vēja ātruma punktiem, kuri ir pierakstīti ar 10 sekunžu intervālu. Diviem rajoniem ar dažādu ainavu noteikti aproksimācijas funkcijas koeficienti, kas raksturo vidējo vēja ātrumu un vidējo kubisko vēja ātrumu sadalījumu pēc augstuma. Rezultāti tiek attēloti tabulu, histogrammu un grafiku veidā. Izveidotas vidējā vēja ātruma un enerǵijas blīvuma sadalījuma līknes ar aproksimāciju līdz $150 \mathrm{~m}$. Pētījuma ietvaros tika veikta akustiskā trokšņa līmen̦a izvietojuma modelēšana virs plānotajiem vēja parkiem. Aprēķini l̦auj noteikt vidi ietekmējošo zonu, ko ietekmē troksnis, un novērtēt projektu atbilstību Latvijas Republikas likumdošanas aktiem, kas nosaka pieḷaujamā trokšṇa līmeṇa normas apdzīvotās vietās. 